\title{
Arabic Resources in American Research Libraries and PL 480
}

BY SEOUD MATTA

IN THE UNITED STATES there are sixtyeight libraries that have noteworthy collections of Arabic publications. Of these, thirty-four libraries possess more than one hundred forty thousand Arabic printed books. ${ }^{1}$ The larger Arabic collections in the United States, according to Mohamed El-Hadi ${ }^{2}$ in his recently completed survey, are to be found in the following thirteen libraries:

Library of Congress

15,575 Vols.

New York Public Library 15,000

Princeton University

Library

University of California

(Los Angeles) Library

Harvard University

Library

University of Utah

Library

Hoover Institution on War,

Revolution, and Peace

Yale University Library

Columbia University

Library

Hartford Seminary

Foundation

University of Michigan

Library

University of California

(Berkeley) Library

University of Chicago

Library

$15,000 "$
$15,000 "$
$10,000 "$
$10,000 \quad "$

9,000

7,000

6,000

$6,000 \quad "$

$6,000 \quad "$

5,000

5,000

The thirteen libraries mentioned above now acquire thousands of Arabic publi-

\footnotetext{
1 Mohamed M. El-Hadi, "Arabic Library Resources in the United States; an Investigation of Their Evolution, Status, and Technical Problems" (PhD thesis, Urbana, III., 1964).

${ }^{2}$ Ibid., p. 48 .
}

Mr. Matta is a member of the Documentation Center for Education, Cairo, UAR, and is a doctoral student in the School of Library Service, Columbia University.

cations annually. "Organizing and serving Arabic publications is still the major problem facing American librarianship. The personnel problem is an important phase of the dilemma. . . . The major bulk of Arabic resources in the above mentioned institutions is not yet cataloged. The back$\log$ in cataloging and the lack of organization of materials hinder the usefulness of such collections." 3

It is the purpose of the following discussion to describe conditions resulting from the current administrative practices of PL 480 regarding cataloging of Arabic materials, and to offer a proposal for performing the task of processing these materials in the United Arab Republic as the best possible solution to this serious problem.

\section{PL 480}

Perhaps the most significant single development for the United States in the acquisition of Arabic materials since the mid-nineteenth century is the United States Public Law 480. This law is aimed at financing programs outside the United States for the following reasons: ${ }^{4}$

1. The analysis and evaluation of foreign books, periodicals, and other materials.

2. The registry, indexing, binding, repro-

Ibid., p. 124.

- Library of Congress, Information Bulletin, XVII (Oetober 27, 1958), 609-10. 
duction, cataloging, abstracting, translating, and dissemination of books, periodicals, and related materials determined to have much significance.

3. The acquisition of such books, periodicals, and other materials and the deposit thereof in libraries and research centers in the United States.

The program started with twelve libraries receiving materials from the United Arab Republic and was extended later to include twenty libraries. "Each of the libraries receiving publications from the UAR is sent the current issues of ten major newspapers, and of some one hundred twenty periodicals. In addition each participant receives commercially published monographs at the rate of twelve to fourteen hundred titles per year and a virtually complete set of current government publications. As of January 1963, after a year of actual operation, the Cairo office had shipped more than one hundred twenty thousand items to participant libraries. ..."

\section{Centralized or Cooperative}

\section{Cataloging of Arabic Materials}

To overcome the difficulties in technical processing of Arabic materials, Harry W. Hazzard $^{6}$ and David Wilder ${ }^{7}$ proposed the establishment of a fully centralized national cataloging system for Arabic or Middle Eastern publications. This would be done in a separate bibliographic center of Near Eastern materials for the use of libraries. Most of the librarians inter-

\footnotetext{
"Robert D. Stevens, "The Library of Congress Public Law 480 Programs," Library Resources and Technical Services, VII (Spring 1963), 180-82.

- Harry W. Hazzard, Bibliographical Resources and Needs in the Social Sciences Relating to the Near and Middle East; a Working Paper Based on a Report Submitted to the Committee on the Near and Middle East Social Science Research Council (New York, March 1957).

T David Wilder, "The Acquisition and Control of Publications from the Middle East; a Report Prepared for the Social Science Research Council, Committee on the Near and Middle East, May 1958," (mimeo) in Association of Research Libraries Farmington Plan Survey ... (final report, 1959), Docket IV-F.
}

viewed by Dr. El-Hadi opposed Hazzard's and Wilder's proposals, and favored the idea of cooperative cataloging described below.

"In January 1962 a questionnaire was sent to the libraries participating in the PL 480 program, asking about the availability of library staff combining language proficiency with cataloging skill. In the case of Arabic, there were a handful of catalogers with language knowledge, and in all there were something in the neighborhood of four hundred man-hours per week of combined Arabic and cataloging knowledge available throughout the nation."8

At the rate of one hour per title, and cutting the available man-hours in half (to allow for sick and annual leaves, coffee breaks, holidays, etc.) it is estimated that it would take all the productive manpower available in the United States twelve years to catch up with the acquisition of the 120,000 volumes shipped in one year from the Cairo office.

"It was obvious from this survey that the research libraries receiving the PL 480 materials are not presently equipped to process them, and that some means of pooling talents will have to be found." As a result, all libraries participating in the PL 480 program have agreed to finance cataloging programs jointly. "Each recipient of a full set of publications from the UAR, excepting Princeton University library which is furnishing the services of a highly skilled cataloger who provides cooperative copy for the bulk of receipts from the UAR, has contributed $\$ 1,111$ for the first year of the cataloging program." 10

Theoretically, Princeton catalogs about forty per cent of PL 480 program's books. The remainder is cataloged by the newly established Arabic language unit of the

\footnotetext{
8 Stevens, op. cit., p. 182-83.

I Ibid., p. 183.

${ }^{10}$ Ibid., p. 181.
} 
foreign languages section of the descriptive cataloging division of the Library of Congress. The cards for Arabic publications are being printed at the Government Printing Office using the existing Arabic type fonts. The results of this cooperative venture are still far from perfection, and the major bulk of Arabic resources is not yet cataloged.

In summing up briefly the state of Arabic collections in American research libraries as seen by Dr. El-Hadi the following conclusions may be drawn:

1. Backlogs number in thousands in each of the libraries surveyed.

2. Trade books and government publications are pouring in thousands through PL 480 and are finding their way to storage areas.

3. Skilled catalogers with language proficiency are scarce in this country, and it seems unlikely that this manpower will increase proportionately to cope with the increased rate of acquisition.

4. There is definitely, in this country, a growing need for faster access to information in Arabic.

\section{Cards-With-Copy Program}

Considering the foregoing problems and to enable PL 480 to achieve a greater degree of effectiveness, it seems logical that one efficient method to deal with Arabic books under present circumstances would be to establish a center for technical processing in Cairo. For perhaps a dollar a copy this proposed center could offer the following:
1. Cataloging using LC-ALA rules.

2. Both LC and Dewey classification numbers.

3. LC subject headings.

4. Offset printing on 100 per cent rag card stock.

5. Full set of catalog cards with each copy.

6. Full set of cross references with each copy.

The following are three valid premises upon which this proposed system could claim superiority:

1. That PL 480 provides for "the registry, indexing, binding, reproduction, cataloging, abstracting, translating, and dissemination of books, periodicals, and related materials. ...."11

2. That there are, in Egypt, over four hundred young people who have majored in library science and who have obtained the BA degree from the department of librarianship and archives, Cairo University, over the past thirteen years of its operation. That under proper planning and administration a few of those young professionals could be selected and trained to do the job in Cairo.

3. That cataloging costs over ten times as much, on a per unit basis, in the United States, and that research libraries in this country are not presently equipped to process their materials.

${ }^{11}$ Library of Congress, op. cit. p. 610 .

\section{Higher Education Facilities}

The Bureau of Higher Education Facilities has been established by U.S. Commissioner of Education Francis Keppel, who has named Peter P. Muirhead as acting associate commissioner to head the new unit. The bureau will administer the Higher Education Facilities Act. 